\title{
A consideration of measuring strain of the very thin geotextile
}

Mitsuru TANAKA \& Masahiko SAKAGUCHI (Technology Research Center of TAISEI CORPORATION)

\begin{abstract}
:
The authors succeeded in measuring strain of the very thin geotextile in the centrifuge scale model test for investigation the dynamic behavior of the reinforced wall with geotextiles. This type of experiments are in good accordance to the law of similarity, but it must be used with very small and thin reinforcement, due to the law of similarity. So we choose the very thin non-woven fabric for reinforcement. It is very difficult to measure strain of the very deformable material like thin geotextile. The selection of strain gauge and the adhesive is very difficult.Especially,in the measuring of dynamic strain like in our case, it can not be sured that result of measuring has high reliability by the normal technique of electrical strain measurement.

The authors obtained complete measuring result of strain of the very thin geotextile(non-woven fabric) in the centrifuge scale model tested under $30 \mathrm{G}$ of centrifugal acceleration using the wide range strain gauge attached to the thin non-woven fabric with special adhesive. These results were well compared to the calculation and other results of large scale model test.
\end{abstract}

\section{概 要:}

筆者等は、ジオテキスタイルを用いた補強土壁の酎震性に関する研究に於て、遠心力載荷実験装 置を用いた小型の振動模型実験を行ない、補強土壁の動的挙動確認の資料の一つとして補強材（ジ オテキスタイル）に作用する引張力を計測した。この種の実験は、相似則に従ったものであるが、 補強材としては、縮小した極めて薄いものを用いなければならない。補強材として極薄の不織布を 採用した。しかし、このような極薄不織布へのひずみ計測は大変困難である。その主な理由は、布 のような伸びの大きな材料のひずみに追随するゲージおよび接着剤の選定が困難なことである。特 に、今回のような動的ひずみ計測に於ては、一般的なひずみ計測技術によって信頼性の高い計測結 果が得られるか否か明かではない。

今回、ジオテキスタイルに特殊な接着材により大ひずみケージを貼って、遠心加速度 $30 \mathrm{G}$ 場に於け る加振実験でひずみ測定を行なった。その結果、極めて薄く伸びの大きな不織布のひずみ測定がで き、計測結果は、大型実験の值や計算值とも整合する良好な結果を得た。 
超薄不織布の応力ひずみ測定に関する一考察

大成建設 (株) 技術研究所

田中 満

坂口昌彦

1.はじめに

筆者等は、ジオテキスタイルを用いた補強土壁の酎震性に関する実験検討を行っている。この中 で遠心力載荷実験装置を用いた小型の振動模型実験を行ない、補強土壁の動的挙動確認の資料の一 つとして補強材（ジオテキスタイル）に作用する引張力を計測した。遠心力載荷実験は、実物の $1 / \mathrm{n}$ に縮尺した模型にn倍の遠心力を載荷することによって、縮尺の影響を除くことができる実験であり、

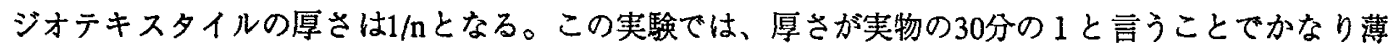
いものを用いる必要があり、補強材として極薄の不織布を採用した。模型内の補強材にに作用する 実験時の引張力は、ひずみを計測しフックの法則によって求めることになる。しかし、このような 極薄不織布へのひずみ計測は大変困難である。その主な理由は、布のような伸びの大きな材料のひ ずみに追随するゲージおよび接着剂の選定が困難なことである。特に、今回のような動的ひずみ計 測に於ては、一般的なひずみ計測技術によって信頼性の高い計測結果が得られるか否か明かではな w。

このようなことから、初期の実験では補強材に作用する引張力を測定することは諦めていた。し かし、筆者等には、飛石防爆シートの応力測定の実績がある11。今回、この経験を活かして、遠心 カ载荷試験用のジオテキスタイルに大ひずみケージを貼って、ジオテキスタイル補強土壁の振動実 験の小型模型を作成し、遠心加速度30G場に於て加振実験を行なった。その結果、極めて薄く伸びの 大きな不織布のひずみ測定ができ、静的な結果はもとより、動的な結果も、大型実験の值や計算値 とも整合する良好な結果を得た。

よって、比較的簡単に超薄不織布の応力測定ができることを明かにしたので以下に報告するもの である。

\section{2.ジオテキスタイルの応カひずみ測定の現状と問題点}

前述したように、ジオテキスタイルの材質は、銅材やコンクリート等の建設材料と比較して、遥 かに柔軟性があり、ひずみ（伸び）を電気的（ストレインゲージ貼付）に計測した例は少ない。

これまで、織布や不織布のひずみ測定はかなりの所でさまざまな方法で実施されている。しかし、 手軽に湘定するのは困難である。特にストレインダージを用いて電気的に測定する方法は、その解 析や評価がなかなか難しいと言われてきた。このジオテキスタイルのひずみ（伸び）を測定するこ とは、ジオテキスタイルを用いた構造物の挙動を把握するためには、必要欠くべからざる測定項目 であるとも言える。

今回、遠心力載荷実験装置を用いた補強土壁の動的実験を行なうにあたり、実験に用いるジオテ キスタイルは、相似則から厚さや剛性を考慮すると極端に薄くしなければならないことになった。 
このことから比較的簡単にその材料選択ができる不織布を補強材として選んだ。しかし、その薄さ が故に補強材のひずみ測定による応力の算出は不可能に近いものがあった。そして、そのひずみ測 定方法も以下の条件を満たしながら、できるだけ簡単かつ真の值に近い測定值を得ることのできる 方法を検討した。

1）極薄不織布のひずみをできるだけ正確に測定できること。

2) 動的ひずみのような振動数が高い場合でもその周波数に追随できること。

3 ）模型内のひずみ測定装置が大掛かりにならないこと。

その検討の中で考慮した、幾つかの方法の内、現実的なものそして、現在実用的に用いられてい るひずみ測定方法で比較的正しい值を得ることのできる、主な計測法を示して、その問題点をあげ て見たい。

(1) ターゲットを膜材料の 2 点に取り付け、2 点間の変位差を光学的に計測する方法。

(2) 2 条の各ワイヤーの各一端を膜材料の 2 点に固定し、各他端をダイヤルゲージ等に結んで

各ワイヤーの変位差を計測する方法。

(3)引っ張り試験のように直接引っ張る場合、引っ張り治具間の変位を計測する方法。

(4) ストレインゲージを貼付し、ストレインゲージ出力を計測する方法。

上に述べたそれぞれの方法を図-1に示す。

それぞれの方法については、長所短所があるが、まず、長所として(1)(2)の方法は、直接的な計測 で、計測結果の可、不可を目視確認できること、(3)の方法は、引っ張り応力と伸びの関係を把握で きること、(4)の方法は、目視できない部分（例、地中）の計測ができることなどが挙げられる。目 に見えないことや直接的ではないことから、若干の不安も残るが、(3)の方法を利用して検定（キャ リブレーション) することによって、伸びから引っ張り応力を求めることができる。

また、それぞれの短所としては、(1)(2)の方法では、膜材料の「初期伸び」まで計測するので、計測 結果が実際の伸びよりも大き目に測定されること、計測開始時に、膜材料に若干でもタルミがある 場合、ゼロ点を把握できないこと、計測機器の設置に関して、センター、機器間の平行度を合わせ 難いことおよび計測機器設置のための広さ（面積）が必要なことなどが挙げられる。(3の方法では、 膜材料の「初期伸び」、チャックで挟む部分のホツレに注意する必要あることや膜材料自体の伸び を計測できない。(4)の測定方法では、ストレインゲージ自体の剛性、計測限界、ストレインゲージ 用接着剂の硬度によっては、計測不能もあり得ることや非直線性、温度変化その他の物理的な影響 があると、計測精度が低下することが挙げられる。

地中に挿入されたジオテキスタイルの効果および性能を遠心力載荷実験によって実験的に把握す る場合は模型が小さいこと、補強材の伸びを目視できないこと、内部にあまり機械的な測定装置を 配置しても重力場の上昇による装置自体の重量増加による荷重としての作用や盛土材料となる砂の 変位などへの影響を考慮して、(4)のストレインゲージを貼付する方式を採用した。 


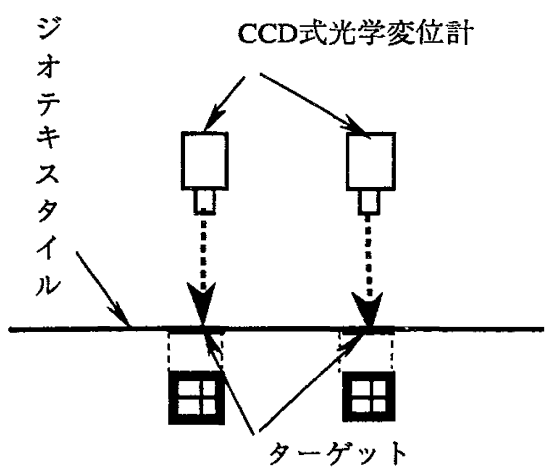

a） 2 点間の変位差を光学的に計測する方法

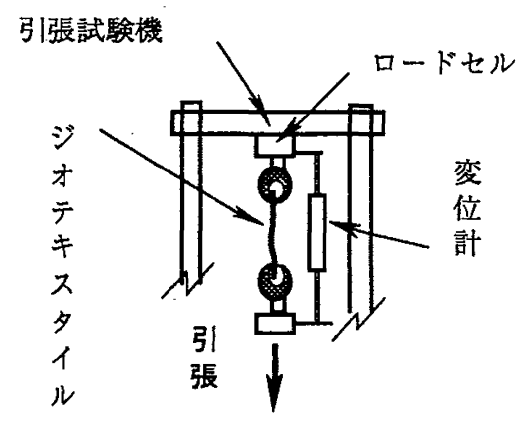

c）引っ張り治具間の変位を計測する方法

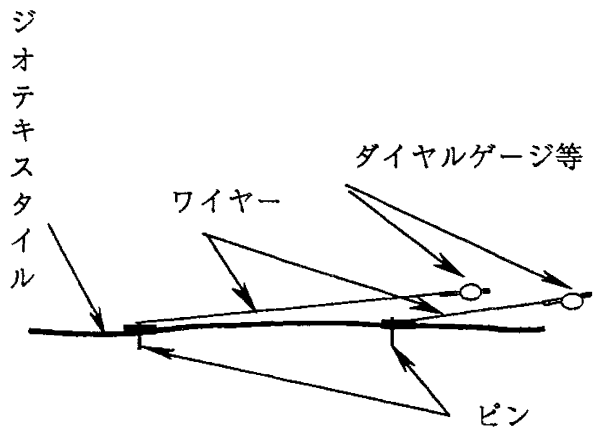

b) 各他端をダイヤルゲージ等に結んで 各ワイヤーの変位差を計測する方法

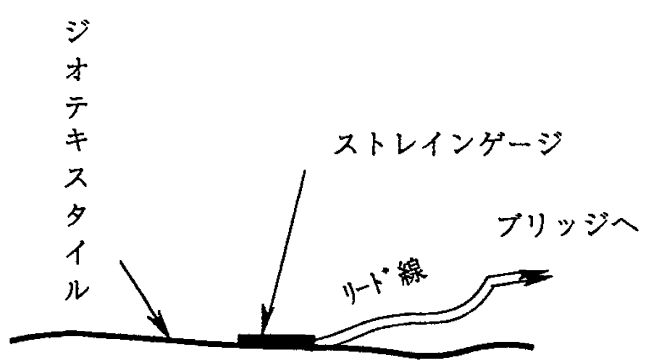

d）ストレインゲージ出力を計測する方法

図-1ジオテキスタイルのひずみ測定方法の例

\section{3.模型実験に用いたひずみ計の設置方法}

厚さ0.11mmの超薄型補強材（不織布：エクレール、6151A）に貼ったストレインゲージは、大ひ ずみゲージ（共和電業、KL-6-120）を採用した。この特徴は、ゲージベースの材質が和紙で、㑉性が ジオテキスタイルよりも低く、最大 $6 \times 10^{4} \mu$ ストレインまでの直線性を保有している。

この大ひずみ用ストレインゲージを、ゴム糊に類する特殊な接着材である柔軟材（共和電業、EC-10） を用いて貼り付けた。この接着材の特徽は、硬化しても、ジオテキスタイルの柔軟性とほほ同等と なるよう調整を施しており、固化しない。

このようにストレインゲージ、接着材は、共に取付け後の伸び率が不織布の伸び率に十分に追随 できるものである。

なお、取付けは、前に示した図-1のd）のように行なった。

\section{4.本方法を採用する基礎となった資料}

使用したゲージおよび接着剤は、かって筆者等が実施した、発破作業時の安全性を確保するため の飛石防爆シートの開発研究に於いて行なった実験で、シートとして用いたジオテキスタイルの 変形を把握するためのひず み測定で採用しており、実績をもつものである゙”。の方法をもとに、 
さらにジオテキスタイルの判性の低いことと薄いことを考慮して今回のひずみ測定方法を決定した。 ここに、過去の実績に於ける方法ならびにその結果を示しておく。

困-2に示すように防爆シートをコンクリート製ヒューム管の上端に設置し設置し爆源を管内で爆発 させた。この時の測定波形例を図-3に示す。若干のずれはあるもののこのような、瞬時のひずみ測定 としては満足できる結果を得ている。

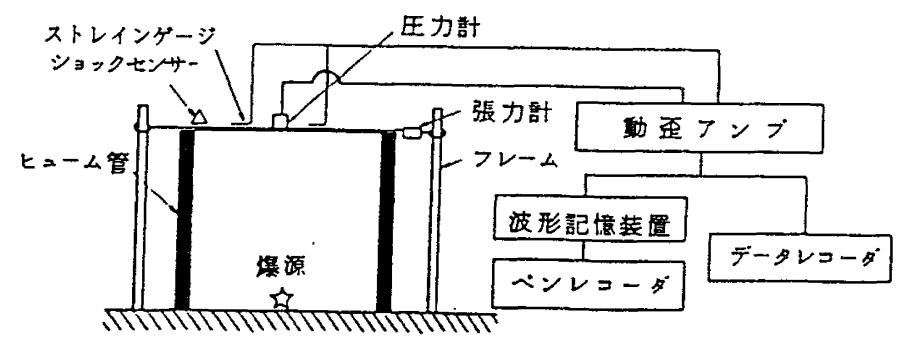

図-2実験装置

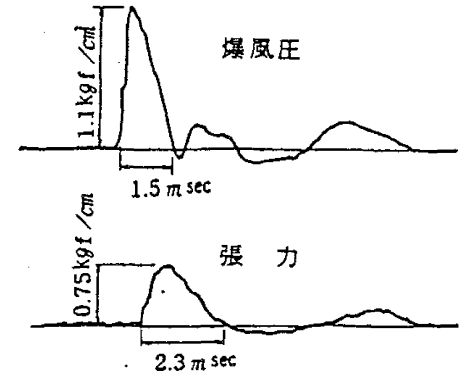

図-3 測定波形例

\section{5.本実倹に於けるひずみ測定方法}

1）ストレインダージを貼った補強材の設置

補強材は、図-4に示すような縮小 模型の中に、図示するような位置に 設置した。ストレインゲージを貼っ た補強材の設置に関しては、リード 線が実質上の補強材となることを極 力避けるために、線はできるだけ細 いものとした。また、模型盛土内の リード線の配線も配慮した。

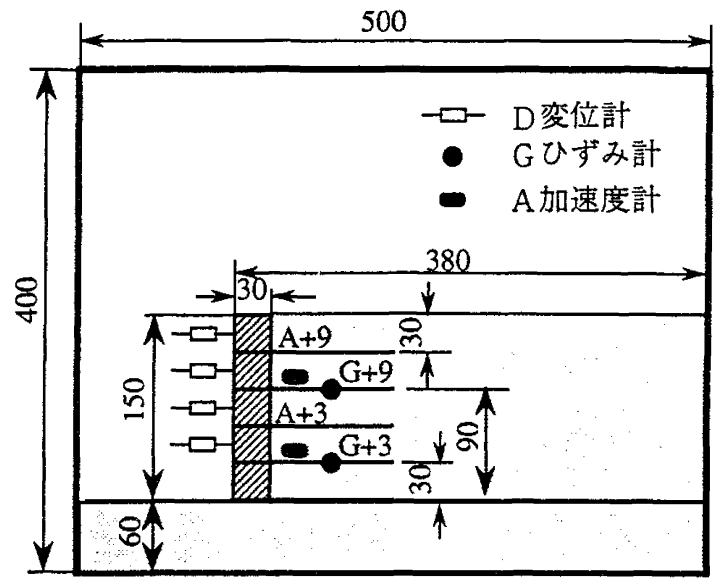

図-4 縮小模型と㭪強材の配置

2 ）ひずみ計を貼った不織布のキャリブレーション

ストレインゲージを貼り付けた不織布は、実験の後、一枚一枚を引張試験機によってキャリブレ ーションをしてその応力〜ひずみ特性を把握した。これは、補強材として用いる不織布が極めて薄 いのですべての不織布の剛性が一様ではないこと、接着に際しては手作業で行なうため、接着材を 同じ厚さ、同じ広さにして貼り付ける作業が不可能に近いことなどが主な理由である。

図-5にその結果の一つを例として示す。 


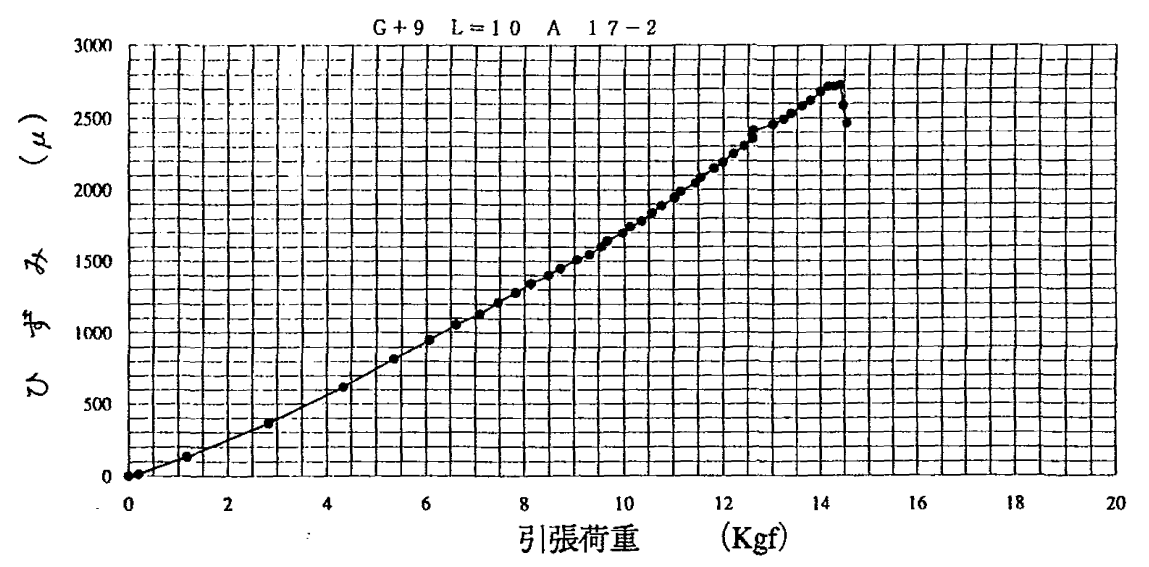

図-5＼cjkstart応カ〜ひずみ引張校正試験結果の一例

また、一枚一枚のキャリブレーションの結果が異ったので、応力を算出する場合はこのおのおの の校正值を尊重した。

\section{6.結果の検証}

1) 静的ひずみ

静的には、キャリブレーションの方法も静的に行なわれており、実際は殆ど問題がない。しかし、 一つの結果として、遠心力載荷実験装置の重力の場が30Gまで上昇する過程の補強材のひずみ計の 値の変化を図-6に示する3)。図-6中のひずみ、重力の場は遠心力の試験の値で示す。盛土天端の変位 およびこの結果をみると土被りが大きくなるにしたがって補強材に作用する引張力の上舁が見られ る。補強材中のひずみを校正值から実大の引張力に換算すると、図 4 中のB+3位置で $560 \mathrm{kgf} / \mathrm{m}$ (土被 り荷重 $5.58 \mathrm{t} \mathrm{f} / \mathrm{m}^{2}$ ) $\mathrm{B}+9$ 位置で305kgf $/ \mathrm{m}$ (土被り荷重 $2.79 \mathrm{t} \mathrm{f} / \mathrm{m}^{2}$ ) であり $\mathrm{B}+3$ 位置が比較的大きめに 出ており土被りに比例している。

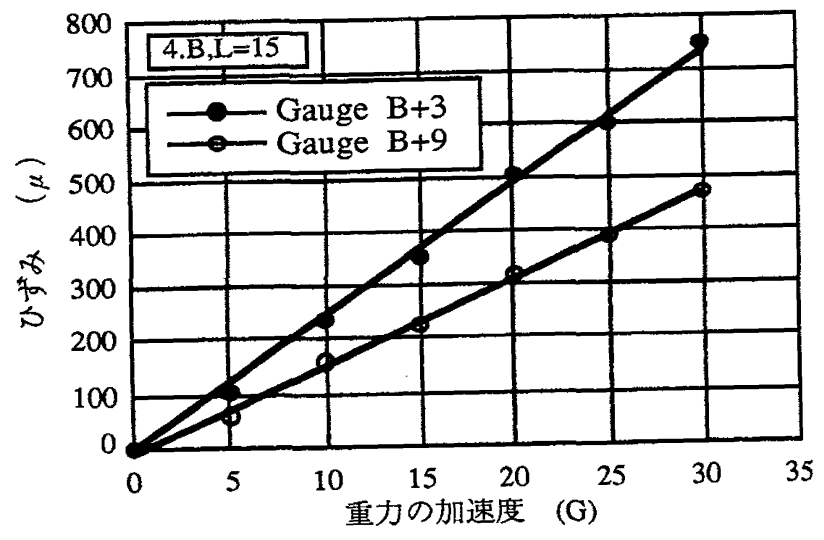

図-6 遠心重力場30Gまでの補強材のひずみの変化 ${ }^{2) 31}$ 


\section{2) 動的ひずみ}

つぎに動的ひずみ測定について、まず、加振の波数に正確に応答しているかをチェックする。当 初、実際の振動数は $100 \mathrm{H} \mathrm{z}$ でありかなり高い振動数なので、ひずみ計や接着材の応答が追随できる か否かが危惧された。図-7に於て波形のA）は加速度計による測定結果を示すものである。また、B） は補強材に貼ったストレインゲージによって測定されたひずみの振幅の波形である。この図を見る と波数は一致しているので、振動数には正しく応答していることがわかる。また、波形から振幅も 振動に忠実に変化しており正確な応答をしていることがわかり、採用したひずみ測定方法が動的に も有効であることが明確である。なお、ひずみ量が正確に測定されているかどうかはこの波形から は判断できない。

図-8に過去実施した、大型模型実験時の加振加速度と補強材に貼ったストレインゲージによるひず みの測定結果を波形で示ず〉。このとき用いた補強材はジオグリッドで剛性も高くストレインゲージ が貼り易い補強材であった。このときの周波数は $4 \mathrm{~Hz} ゙$ あり、振動数が遠心力載荷実験装置の小型模 型実験で実施したものより数十倍遅いので、少なくとも遠心力載荷実験の模型による測定結果より は良好な結果を得ているはずである。この結果と遠心力載荷実験装置の小型模型実験結果と比較し てみると加速度波形への追随性は、ほとんど同様な結果を得ている。ただし、図-7では補強材のひず み波形は反転して表示されている。

これらのことより、測定結果の有効性が実証されるものである。

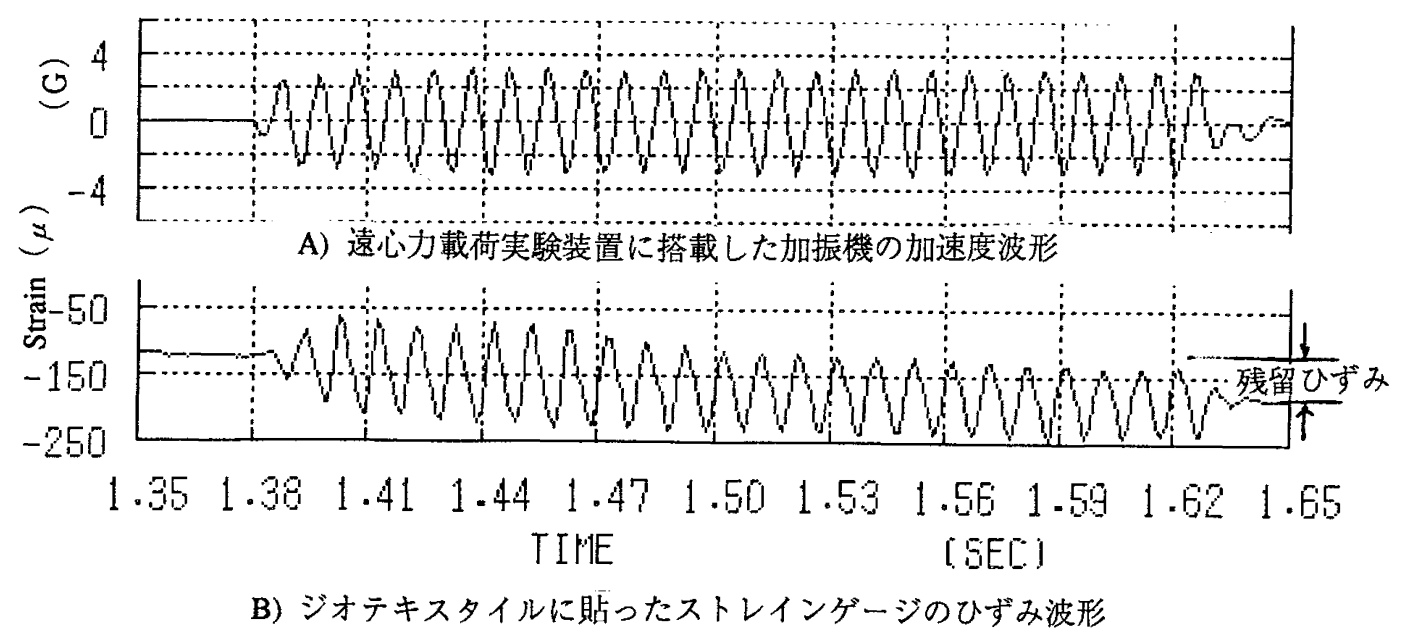

図-7 遗心力載荷実験に於ける3G加振時の加速度計とひずみの答波形 


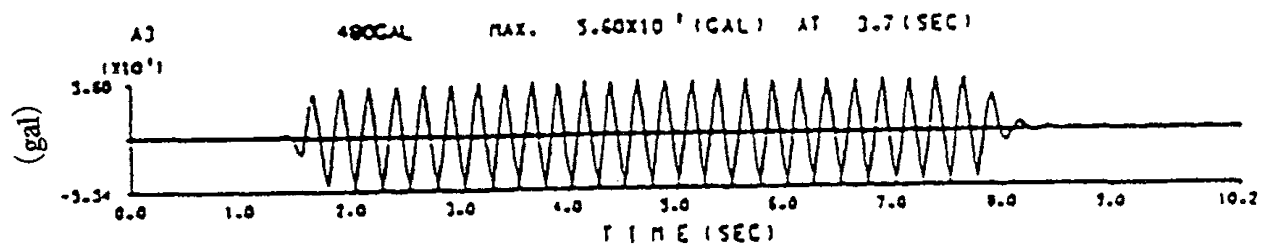

A) 振動台の加速度波形

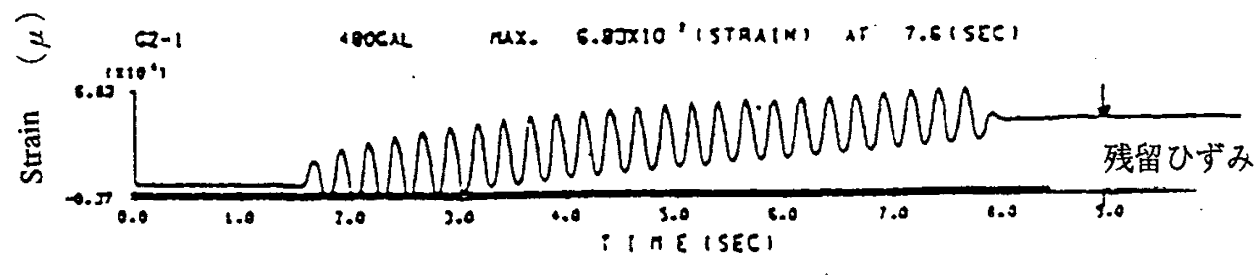

B) ジオグリッドに貼ったストレインゲージのひずみ波形

図-8 大型模型実験に於ける480gal加振時の加速度計とひずみの応答波形4)

\section{7.おわりに}

今回亟めて小さな模型実験の中に於て、特に剛性の低い極薄ジオテキスタイルのひずみの測定が 可能なことを立証することができた。これをもとに今後も実験研究を行なってゆきたい。さらに、 この結果が、他部所に於かれて今後実施されるであろうジオテキスタイルを用いたあらゆる小型模 型実験の手法を拡張するための一助となることを希望する次第である。最後に、不織布の提供と物 性に関する資料の提供を戴いた東洋紡績（株）の永野豊氏ならびに石川雅洋氏に記して感謝する次 第である。

\section{参考文献：}

1)水野、田中、相賀、福島、中村「防爆シート開発のための基礎研究-その2 ヒューム管によ る小規模爆破実験-」工業火薬協会昭和63年度年会講演集,Jun,1988

2)M.Sakaguchi,K.Yamada,M.Tanaka"Prediction of Deformation of Geotextile Reinforced Walls Subjected to Earthquakes"The 5th Intrenational Geotextiles,Geomembranes and Related Products.Singapore,Sept.1994.

3)坂口、山田、田中「ジオテキスタイルを用いた補強盛土の変形の予測について」第49回土木 学会全国大会年次学術講演会、9,1994.

4)M.Sakaguchi,K.Yamada,K.Nagura,M.Muramatsu"Résistance au Sismique en Ouvrages de Soutènement Renforcés par Géosynthétiques" La réalisation des actes de Géotextiles-Géomembranes RENCONTRES93.le Sept. 1993.Joué-les-Tours France. 